Mag.

Tanja Čelebič

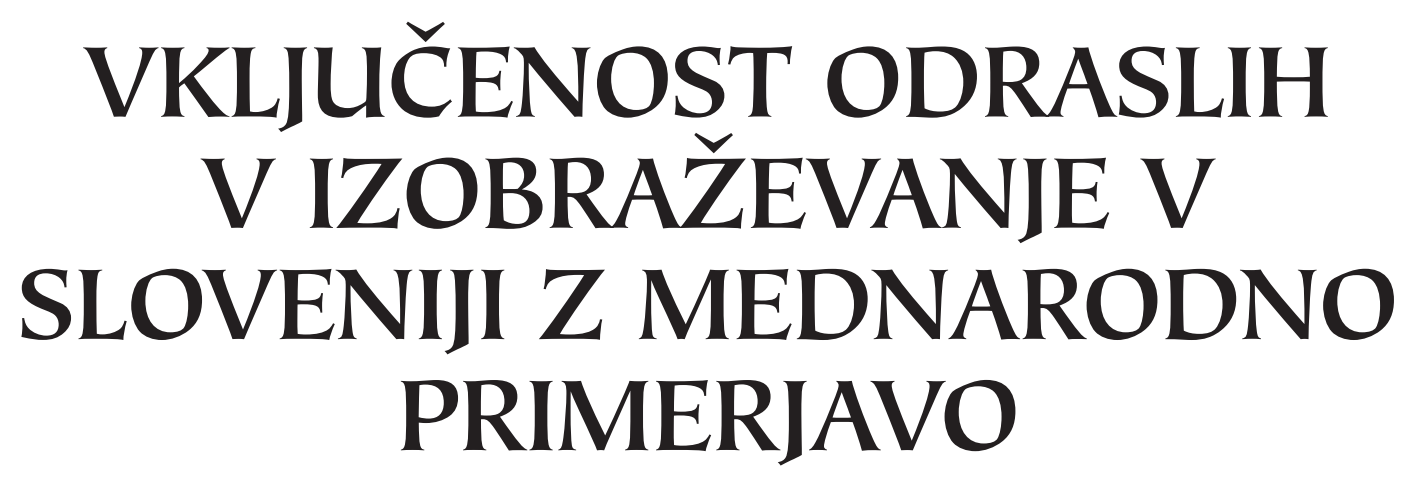

POVZETEK

Avtorica v prispevku najprej prikazuje koristi, ki jih imajo posameznik, družba in gospodarstvo od izobraževanja. Bolje izobraženi imajo v povprečju v primerjavi s slabše izobraženimi višje osebne dohodke, stopnja tveganja rev̌šcine je pri njih nižja, izobraževanje pa pozitivno vpliva tudi na gospodarsko rast. Nato avtorica na osnovi razpoložljivih domačih in mednarodnih statističnih podatkov prikaže gibanje vpisa odraslih v izobraževanje v Sloveniji z mednarodno primerjavo $z$ drugimi evropskimi državami in spreminjanje izobrazbene strukture odraslega prebivalstva $v$ obdobju po letu 2000. Primerjava Slovenije z drugimi evropskimi državami in z evropskim povprečjem pokaže, da je vključenost odraslih v starosti od 25 do 64 let v vseživljenjsko učenje s 14,8 odstotka v letu 2007 ena najvišjih med evropskimi državami in višja od omenjenega povprečja. Tudi vključenost odraslih $v$ srednje in terciarno izobraževanje je višja od evropskega povprečja in se je v obdobju od 2000 do 2006 povečala. Izobrazbena struktura odraslega prebivalstva se postopoma izboljšuje. V obdobju od 2000 do 2007 se je zmanjšal delež prebivalstva s končano največ osnovno šolo in povečal delež prebivalstva s terciarno izobrazbo. Vključenost odraslih v starosti od 25 do 64 let v neformalno izobraževanje se je v obdobju od 2003 do 2007 malenkost povečala, $v$ vključenosti se kažejo velike razlike glede na dosě̌eno izobrazbo. Kljub pozitivnim gibanjem pri tem pa sta razvojna izziva za v prihodnje povezana s spodbujanjem večje vključenosti starejših in nižje izobraženih v formalno in neformalno izobraževanje.

Ključne besede: izobraževanje odraslih, vključenost v izobraževanje, izobrazbena struktura, koristi od izobraževanja, vseživljenjsko učenje

$\mathbf{V}_{\mathrm{a}}$ najrazličnejši, pridobljeno znanje lahko uporabimo v različnejših okoliščinah in okoljih, njegovi učinki pa so mnogoteri in se kažejo na različnih ravneh. Vseživljenjsko učenje je pomembna sestavina $\mathrm{v}$ okviru nacionalnih in mednarodnih strateških dokumentov (lizbonska strategija, memurandum o vseživljenjskem učenju, resolucija o nacionalnem programu izobraževanja odraslih v Republiki Sloveniji do leta 2010, strategija vseživljenjskosti učenja in podobno). Resolucija o nacionalnem programu izobraževanja odraslih v Republiki Sloveniji do leta 2010 (Ur. L., št. 70, 2004) kot eno od prednostnih področij navaja izobraževanje za dvig izobrazbene ravni, odraslim pa naj bi zagotovili različne možnosti za pridobivanje oziroma dokončanje osnovnošolske, srednješolske in višje strokovne izobrazbe (Resolucija o nacionalnem programu izobraževanja od- 
raslih v Republiki Sloveniji do leta 2010 (Ur. 1. št. 70/2004)).

Prispevek najprej prikazuje koristi, ki jih imajo od izobraževanja posameznik, družba in gospodarstvo, nato na osnovi dosegljivih domačih in mednarodnih podatkov (SURS, Eurostat) gibanje vključenosti odraslih $\mathrm{v}$ formalno in neformalno izobraževanje in spreminjanje izobrazbene strukture v Sloveniji z mednarodno primerjavo $\mathrm{z}$ drugimi evropskimi državami. Prikazano je obdobje po letu 2000, zadnje leto pa predstavlja leto, za katerega so na voljo zadnji dosegljivi podatki.

\section{UČINKI IZOBRAŽEVANIA}

Glede na to, da so učinki izobraževanja (lahko jih imenujemo tudi koristi od izobraževanja) zelo raznoliki in se kažejo na različne načine, jih je smiselno razvrstiti po izbranih kriterijih. Prvi možni kriterij se nanaša na to, kdo prejema koristi od izobraževanja (posameznik, družba in gospodarstvo). Drugi možni kriterij je narava teh učinkov (ekonomski in neekonomski). V nadaljevanju najprej prikazujemo učinke na ravni družbe in vpliv izobraževanja na gospodarsko rast.

OECD v publikaciji z naslovom Tertiary education for the knowledge society družbene koristi od izobraževanja razdeli na zasebne koristi od izobraževanja in zunanje ekstarnalije izobraževanja (Santiago, Tremblay, Basri, Arnal, 2008).

Zasebne koristi od izobraževanja so koristi, ki jih ima od izobraževanja posameznik, ki je vključen v izobraževanje. Posameznik ima od izobraževanja lahko denarne in/ali nedenarne koristi. Med denarne koristi sodijo (vseživljenjski) dohodek, verjetnost brezposelnosti. Na ravni posameznika izobraževanje povečuje njegovo kreativnost, samoiniciativnost, fleksibilnost in konkurenčnost na trgu dela ter vodi k višjim zaslužkom. Med nedenarne koristi sodijo zdravje (zdravstveno stanje), stopnja tveganja revščine, delovni pogoji, kognitivni razvoj otrok, osebnostni razvoj in vključenost $\mathrm{v}$ družbo (Temple, 2001: 63; Woessmann in Schultz, 2006: 1, 3; Vossensteyn, 2007). Zunanje ekstarnalije izobraževanja so koristi od izobraževanja, ki jih prejemajo drugi posamezniki $\mathrm{v}$ družbi v sedanji in bodočih generacijah in ne posameznik, ki je vključen v izobraževanje. Sem sodijo učinki na zdravje (manjša smrtnost dojenčkov, daljša življenjska doba, nižja stopnja kriminalitete, nižja stopnja revščine in podobno) (Santiago, Tremblay, Basri, Arnal, 2008: 36). Kaže se tudi pozitivna povezanost med stopnjo izobrazbe in zdravjem prebivalstva (višje vanja so lahko zasebne (npr. denar) ali zunanje (npr. daljša življenjska doba prebivalstva, nižja stopnja revšcine ipd.).
Koristi od izobražeizobraženi živijo $\mathrm{v}$ povprečju dlje časa od nižje izobraženih) (Temple, 2001: 63; Woessmann in Schultz, 2006: 1, 3). Zgornje navedbe potrjujejo tudi empirični podatki. V Sloveniji je stopnja brezposelnosti pri terciarno izobraženih posameznikih nižja kot pri nižje izobraženih (gl. Sliko 1). Višja stopnja izobrazbe

\section{Slika 1: Stopnja brezposelnosti in stopnja tveganja revščine, skupaj in glede na doseženo izobrazbo v letih $2007^{*}$ in $2006{ }^{*}$, Slovenija, v \%}

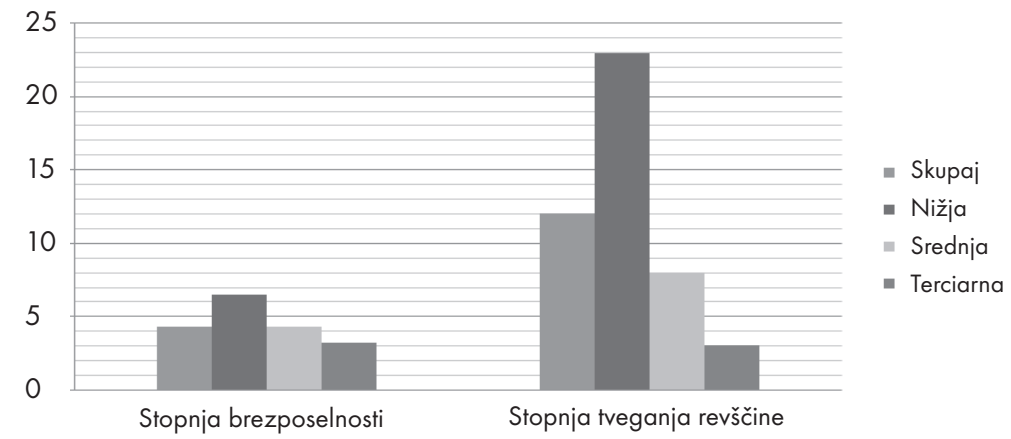

Vir: Population and social condition - Eurostat Queen tree, 2008.

Opomba*: Pri stopnii brezposelnosti je zajeta starostna skupina od 25 do 64 let, pri stopnji tveganja revščine pa starostna skupina 18 let ali več. Za stopnjo brezposelnosti so zadnji podatki na voljo za leto 2007, za stopnjo tveganja revščine pa za leto 2006. Upoštevana je stopnja tveganja revščine po socialnih transferiih. 
Slika 2: Relativni zaslužki (od zaposlitve) prebivalstva, glede na starost in spol, srednješolska izobrazba = 100, Slovenija, 2004

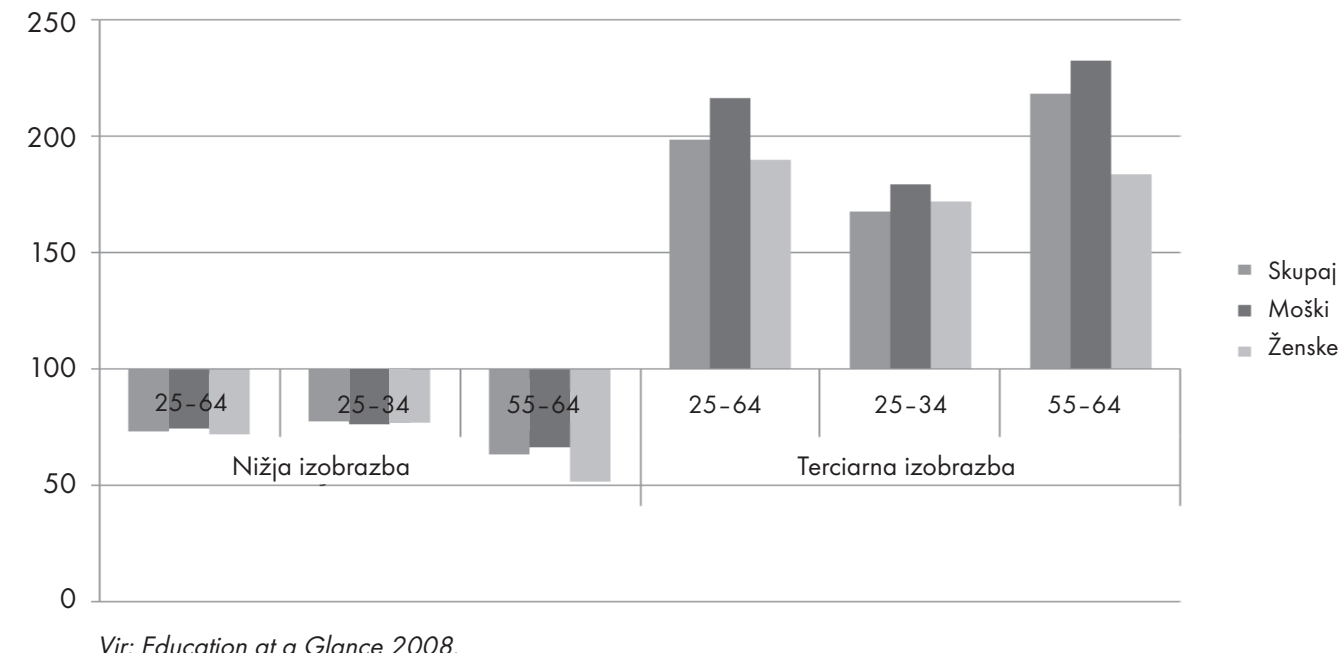

tudi zmanjšuje tveganje revščine, ki so ji najbolj podvrženi posamezniki z nižjo izobrazbo, in pozitivno vpliva na socialno vključenost posameznika. Posamezniki s terciarno izobrazbo imajo $\mathrm{v}$ povprečju višje plače $\mathrm{v}$ primerjavi s srednje in nižje izobraženimi, kar kaže Slika 2. Izobraževanje ima veliko različnih učinkov, ki se kažejo na ravni družbe, vendar pa je vse učinke izobraževanja pogosto težko (natančno) izmeriti.

Formalno in neformalno izobraževanje je pomemben dejavnik gospodarske rasti. Zaradi globalizacije, tehnološkega napredka, hitrega spreminjanja narave dela in staranja prebivalstva ima pomembno težo. Predstavlja pomemben vir izboljševanja kakovosti človeškega kapitala in pozitivno vpliva na gospodarsko rast. Čeprav ima gospodarstvo korist tako od formalnega kot od neformalnega izobraževanja in informalnega učenja, pa se zaradi omejitev v zvezi s podatki na mednarodni ravni dosegljive študije praviloma osredotočajo na učinke formalnega izobraževanja. Daljše povprečno trajanje (formalnega) izobraževanja, merjeno s povprečnim številom let šolanja delovno aktivnega prebivalstva, pozitivno vpliva na produktivnost posameznika in organizacije ter na gospodarsko rast. V povprečju imajo države $\mathrm{z}$ daljšim povprečnim trajanjem izobraževanja hitrejšo gospodarsko rast. Raziskava Hanuska in Wossmana (2007) je pokazala, da leto dni izobraževanja poveča gospodarsko rast za 0,58 odstotne točke. Pri tem je povezava med doseženo izobrazbo in BDP/prebivalca verjetno obojestranska. Daljše povprečno trajanje izobraževanja pozitivno vpliva na BDP države in rast BDP. Med povprečnim trajanjem izobraževanja in BDP na prebivalca obstaja pozitivna korela-

Med državami se kažejo razlike v vplivu povprečnega števila let šolanja na gospodarsko rast, na kar vplivajo različni dejavniki (institucionalno okolje, čas uporabe s šolanjem pridobljenega znanja, ${ }^{1}$ odprtost gospodarstva v mednarodno okolje in podobno) (Hanusek, Wossmann, 2007). Prav tako podatki kažejo pozitivno povezanost med deležem prebivalstva s terciarno izobrazbo in BDP na prebivalca. Države z višjim deležem prebivalstva s terciarno izobrazbo imajo v povprečju tudi višji BDP na prebivalca. Omeniti velja, da je poleg povprečnega števila let šolanja z vidika produktivnosti in gospodarske rasti pomembna tudi kakovost izobraževanja (merjena s tem, kaj posameznik zna). 
cija; države z daljšim povprečnim trajanjem izobraževanja imajo v povprečju tudi višji BDP.

\section{VKLJUČENOST V VSEŽIVLJENJSKO UČENJE}

Zaradi staranja prebivalstva in podaljševanja delovne dobe lahko pričakujemo naraščajoče potrebe po izobraževanju v vseh starostnih skupinah. Nekateri motivi za izobraževanje, kot je zahteva delodajalca, pridobitev ali ohranitev zaposlitve ali menjava delovnega mesta, postajajo enako pomembni ne glede na starost posameznika. Vseživljenjsko učenje ima pomembno mesto tudi v okviru lizbonske strategije, ki pa pomen izobraževanja vidi predvsem v povezavi z zaposlovanjem, medtem ko zanemarja preostale vidike izobraževanja (izobraževanje za osebnostni razvoj, za aktivno državljanstvo, za uspešno opravljanje dejavnosti, ki jih posameznik opravlja v prostem času, in podobno).

\section{OKVIR}

Evropska komisija je za merjenje vključenosti v vseživljenjsko učenje razvila kazalnik vključenosti v vseživljenjsko učenje. Kazalnik meri vključenost prebivalstva, starega od 25 do 64 let, v izobraževanje in usposabljanje v obdobju šti- rih tednov pred izvajanjem ankete. Izraz vseživljenjsko učenje je neustrezen, saj vseživljenjsko učenje vključuje vse učne dejavnosti, izpeljane v celotnem življenju, s ciljem izboljšati znanje, spretnosti in kompetence $\mathrm{v}$ osebnostnem, državljanskem, družbenem in $\mathrm{z}$ zaposlovanjem povezanem vidi$\mathrm{ku}$, in ne le tistih, ki so izpeljane v starosti od 25 do 64 let. Prav tako vseživljenjsko učenje obsega poleg formalnega in nefor-

Slovenija presega
evropski cilj glede
vkliučenosti odra-
slih v vseživljenj-
sko učenje.
malnega izobraževanja tudi aformalno učenje, ki pa ga obravnavani kazalnik ne upošteva. Evropski cilj na področju izobraževanja je, da naj bi evropske države do leta 2010 dosegle vsaj 12,5-odstotno vključenost prebivalstva v starosti od 25 do 64 let v vseživljenjsko učenje, Slovenija pa ta cilj že presega. Pri nas je v primerjavi z večino drugih evropskih držav vključenost odraslih v vseživljenjsko učenje ${ }^{2}$ razmeroma visoka. V letu 2007 je bilo v razne oblike vseživljenjskega učenja (formalno in neformalno izobraževanje) vključenih 14,8 odstotka prebivalstva v starosti od 25 do 64 let, s čemer je preseženo evropsko povprečje (EU27: 9,5 odstotka), vendar pa Slovenija precej zaostaja za nekaterimi severnoevropskimi državami (gl. Sliko 3). Čeprav je, primerjalno gledano, vključenost odraslih v vseživljenjsko učenje v Sloveniji razmeroma visoka, pa se že tretje leto zapored znižuje.

Slika 3: Vključenost odraslih v starosti od 25 do 64 let v vseživlienjsko učenje, Slovenija in države EU, v letu 2007, v \%

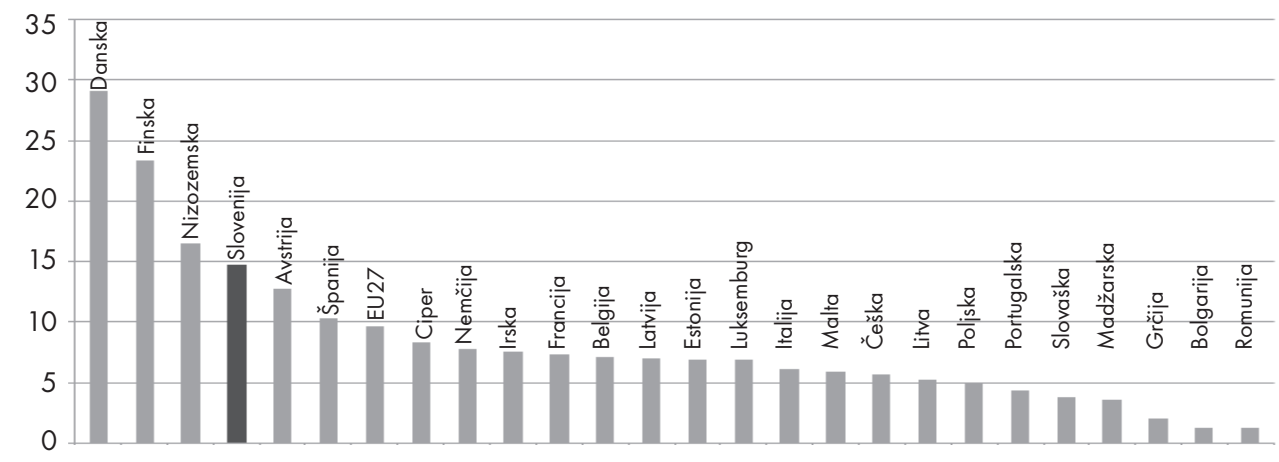

Vir: Population and social condition - Eurostat Queen tree, 2008. 
Čeprav je vključenost v vseživljenjsko učenje tako v mlajših kot tudi v starejših življenjskih obdobjih pomemben dejavnik ohranjanja konkurenčnega položaja na trgu dela, pa v Sloveniji vključenost odraslega prebivalstva v vseŽivljenjsko učenje s starostjo ${ }^{3}$

Slovenija prednjači pri vkljucevanju mlajših, zaostaja pa pri vključevanju starejših $v$ vseživljenjsko učenje.

naglo upada. V vseh starostnih skupinah je vključenost odraslih v vseživljenjsko učenje višja od evropskega povprečja (glej Sliko 4), vendar pa v Sloveniji upada hitreje od evropskega povprečja, razlika med vključenostjo najmlajše in najstarejše obravnavane starostne skupine v vseživljenjsko učenje pa je največja med evropskimi državami. Razlogov za razlike v stopnji vključenosti v vseživljenjsko učenje glede na starost je več. Mlajši običajno od izobraževanja pričakujejo večje koristi (na primer, napredovanje v karieri) kot starejši kolegi, poleg tega je pri

Slika 4: Vključenost odraslih v starosti od 25 do 74 let v vseživljenjsko učenje, skupaj in glede na starost, Slovenija in povprečje EU, v letu 2007, v \%

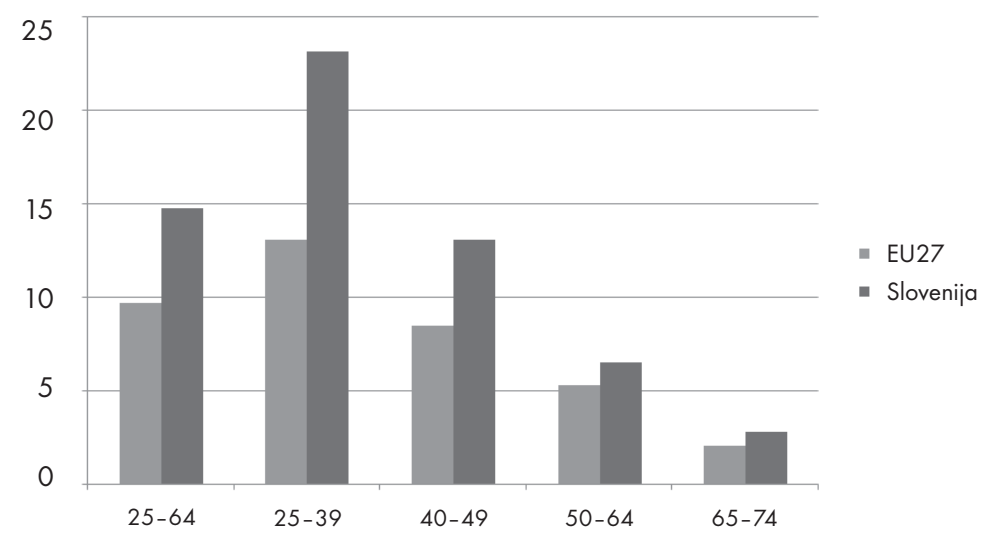

Vir: Population and social condition - Eurostat Queen tree, 2008.

nekaterih starejših pogosto prisoten tudi predsodek, da so za izobraževanje že prestari. Možen razlog je tudi ta, da so delodajalci manj pripravljeni vlagati v starejše zaposlene kot v njihove mlajše sodelavce. Opozoriti velja, da izobraževanje starejših ne prinaša koristi le tistim, ki so zaposleni, ampak tudi upokojencem. Prebivalstvo v Sloveniji se stara, delež prebivalstva $\mathrm{v}$ starosti 65 let ali več se povečuje. Izobraževanje v starosti prispeva h krepitvi mentalne sposobnosti, vzdrževanju stikov z okolico, starejši, ki se izobražujejo, pa so v povprečju dlje časa sposobni skrbeti zase.

\section{VKLJUČENOST V FORMALNO IZOBRAŽEVANJE}

V Sloveniji je vključenost odraslih v starosti od 25 do 64 let v formalno izobraževanje višja od evropskega povprečja, Slovenija se po vključenosti $\mathrm{v}$ formalno izobraževanje uvršča v zgornjo tretjino evropskih držav (gl. Sliko 5); v letu 2006 je znašala 4,4 odstotka, v primerjavi z letom 2000 pa se je povečala za 1,9 odstotne točke. Ob tem pa je treba opozoriti, da vključenost $\mathrm{v}$ formalno izobraževanje s starostjo razmeroma hitro upada, čeprav se s starostjo izobrazbena struktura prebivalstva slabša. Struktura odraslih v starosti od 25 do 64 let, vključenih v formalno izobraževanje kaže, da je večina vpisana $\mathrm{v}$ terciarno izobraževanje. ${ }^{4}$ V Sloveniji je vključenost prebivalstva v starosti od 25 do 64 let v srednješolsko izobraževanje višja kot $\mathrm{v}$ večini drugih evropskih držav in višja od evropskega povprečja; v letu 2006 je znašala 0,8 odstotka (evropsko povprečje: 0,5 odstotkov) in se je v primerjavi z letom 2000 malenkost povečala. Najvišje stopnje vključenosti v srednje izobraževanje med evropskimi državami imajo z nekaj več oziroma malo manj kot tremi odstotki Belgija, Finska in Švedska. Čeprav s starostjo delež prebivalstva z doseženo srednješolsko izobrazbo upada, v višjih starostnih skupinah upadajo tudi stopnje vključenosti prebivalstva $\mathrm{v}$ srednješolsko izobraževanje. V obdobju od 2000 do 2006 se je delež odraslega prebivalstva, vključenega $v$ srednje šole, najbolj povečal pri starostni skupini od 20 do 29 let, sledi starostna skupina od 30 do 39 let, najmanj 
Slika 5: Vključenost odraslih $v$ starosti od 25 do 64 let $v$ posamezne ravni formalnega izobraževanja, Slovenija in države EU, v letu 2006, v \%

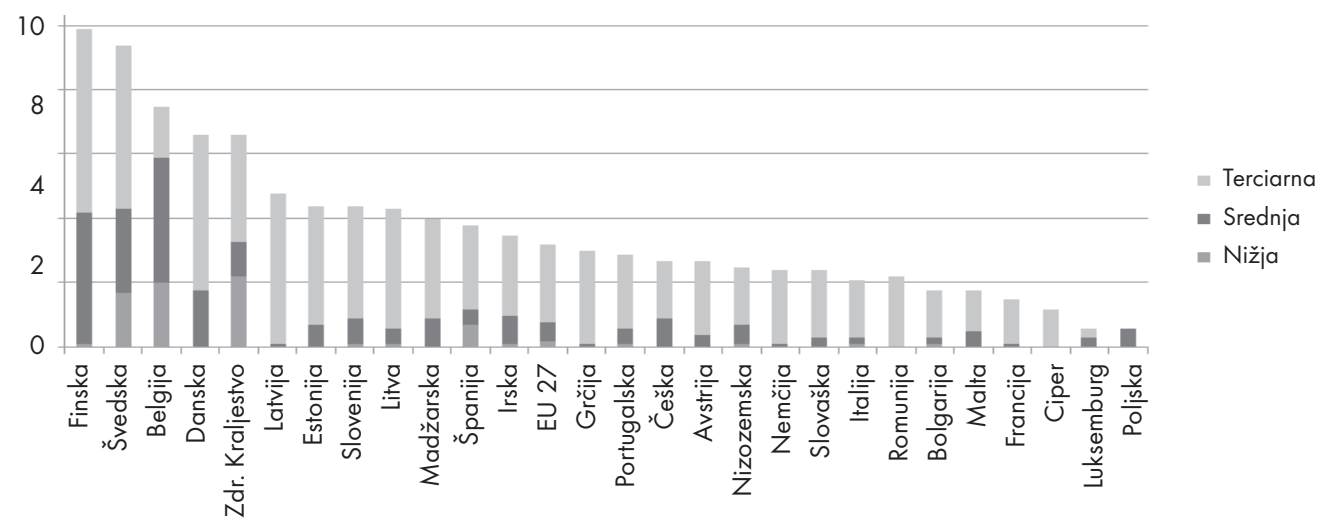

Vir: Population and social condition - Eurostat Queen tree, 2008.

pa se je vključenost v srednje šole povečala pri starostni skupini od 40 do 64 let, kjer se vključenost vseskozi ohranja na zelo nizki ravni.

Povečuje se tudi vključenost odraslega prebivalstva v terciarno izobraževanje. V Sloveniji je bilo v letu 2006 v terciarno izobraževanje vključenih 3,5 odstotka prebivalstva $\mathrm{v}$ starosti od 25 do 64 let, kar je nad evropskim povprečjem (2,4 odstotka), vendar pa je Slovenija zaostajala za nekaterimi severnoevropskimi državami, ki imajo najvišje stopnje vključenosti: Finska (5,7 odstotka), Švedska (5,1 odstotka) in Danska (4,8 odstotka). To so obenem tudi države $\mathrm{z}$ visokim deležem prebivalstva s terciarno izobrazbo in visokim bruto družbenim proizvodom na prebivalca.
Vključenost odraslih v terciarno izobraževanje se je v Sloveniji v obdobju od 2000 do 2006 povečala hitreje od evropskega povprečja (Slovenija: za 1,5 odstotne točke, EU27: 0,5 odstotne točke).

Zaradi vključenosti mladih v starosti od 15 do 19 let in odraslih v starosti od 25 do 64 let v formalno izobraževanje se spreminja tudi izobrazbena struktura prebivalstva. V Sloveniji se je v obdobju od 2000 do 2007 po podatkih ankete o delovni sili za drugi kvartal zmanjšal delež prebivalstva $v$ starosti od 25 do 64 let s končano največ osnovno šolo, povečal pa se je delež prebivalstva s terciarno izobrazbo. Delež prebivalstva v starosti od 25 do 64 let z največ osnovnošolsko izobrazbo je znašal 17,7

Motivacijo za vključitev v terciarno izobraževanje pri odraslih verjetno povečujejo tudi pričakovane koristi od pridobljene terciarne izobrazbe (višina pričakovanega osebnega dohodka). Podatki OECD (Education at a Glance 2008) namreč kažejo, da so relativni zaslužki od zaposlitve pri posameznikih, starih od 25 do 64 let, v Sloveniji v povprečju skoraj še enkrat višji kot pri srednješolsko izobraženih. Razmerje med zaslužki srednje in terciarno izobraženih pa je v Sloveniji med najvišjimi v primerjavi z državami, ki so članice OECD. Vključenost v terciarno izobraževanje s starostjo po pričakovanju upada, vendar pa je vključenost v terciarno izobraževanje tudi v starostnih skupinah od 30 do 39 let in 40 let ali več višja od evropskega povprečja; v letu 2006 je v starostni skupini od 30 do 39 let znašala 4,5 odstotka (EU27: 3,1 odstotkov), v starostni skupini od 40 do 64 let pa 0,9 odstotka (EU27: 0,5 odstotka). 
Slika 6: Izobrazbena struktura prebivalstva v starosti od 25 do 64 let, Slovenija in države EU, v letu 2007, 2. kvartal

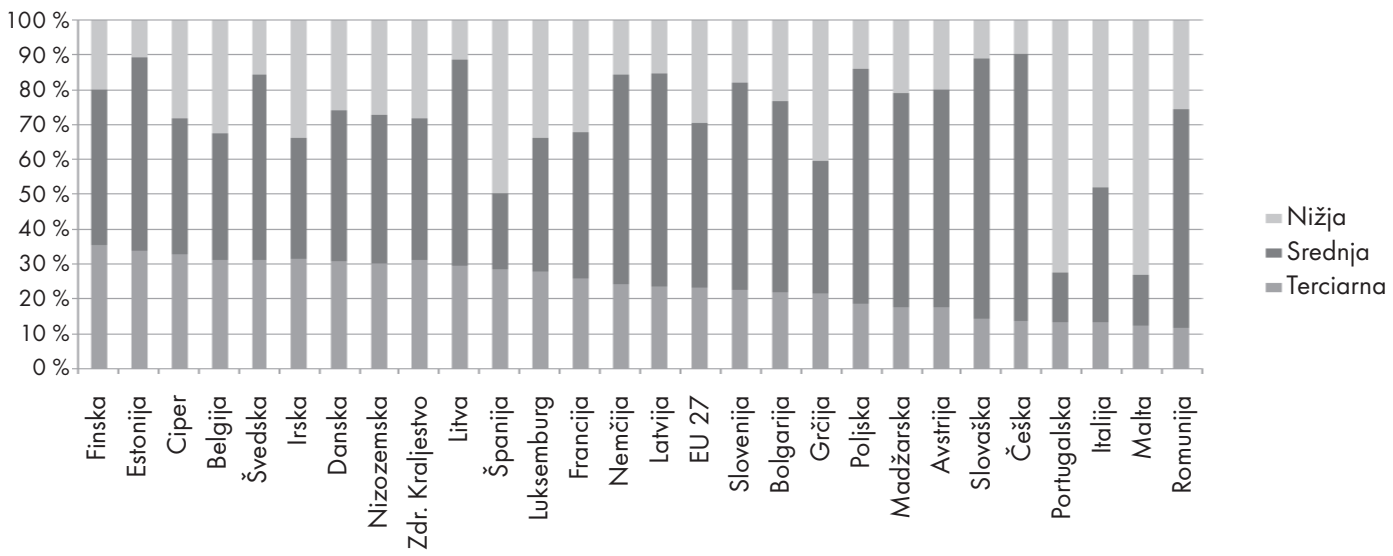

Vir: Population and social condition - Eurostat Queen tree, 2008

odstotka in je nižji kot v večini drugih evropskih državah in nižji od evropskega povprečja, v obdobju od 2000 do 2007 pa se je precej znižal (za 7,4 odstotne točke). Delež prebivalstva s srednjo izobrazbo se je v obravnavanem obdobju ohranjal na približno enaki ravni in je bil višji od omenjenega povprečja. Delež prebivalstva v starosti od 25 do 64 let s terciarno izobrazbo je v letu 2007 znašal 22,9 odstotka
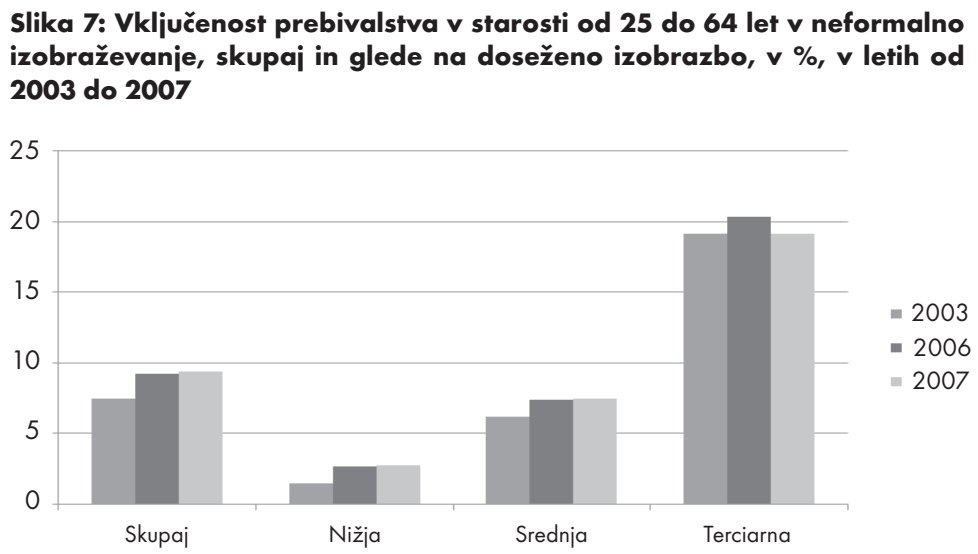

Vir: Anketa o delovni sili, interni podatki SURS; lastni preračuni.

Opomba: v letu 2003 je prišlo do spremembe metodologije, zato je v grafu prikazano le obdobje od 2003 do 2007. in je bil malenkost nižji od evropskega povprečja, ki je tega leta znašalo 23,3 odstotka (gl. Sliko 6), vendar pa se je zaostanek Slovenije za navedenim povprečjem v obdobju od 2000 do 2007 precej zmanjšal. Delež prebivalstva v starosti od 25 do 64 let s končano vsaj srednjo šolo se je v obdobju od 2000 do 2007 povečal za 5,9 odstotne točke in v letu 2007 znašal 82,3 odstotka.

\section{VKLJUČENOST ODRASLIH V NEFORMALNO IZOBRAŽEVANJE}

Vključenost v neformalno izobraževanje odraslim omogoča, da nadgrajujejo in dopolnjujejo $\mathrm{v}$ formalnem izobraževanju pridobljena znanja, kar pozitivno vpliva na njihovo fleksibilnost. V Sloveniji je bilo v letu 2007 v neformalno izobraževanje vključenih 9,4 odstotka prebivalstva $\mathrm{v}$ starosti od 25 do 64 let (za evropske države primerljivih podatkov za obravnavano obdobje nimamo na voljo), kar je malenkost več kot leta 2006 (gl. Sliko 7). Pri vključenosti v neformalno izobraževanje se kažejo velike razlike v vključenosti glede na doseženo izobrazbo. Vključenost prebi- 
valstva $\mathrm{z}$ nižjo izobrazbo $\mathrm{v}$ neformalno izobraževanje je bila v letu 2007 6,8-krat nižja od vključenosti terciarno izobraženega prebivalstva.

\section{ZAKLJUČEK}

Čeprav se izobrazbena struktura prebivalstva v Sloveniji izboljšuje in je vključenost odraslega prebivalstva $\mathrm{v}$ srednje in terciarno izobraževanje in vseživljenjsko učenje višja od večine evropskih držav in višja od evropskega povprečja, so prisotni nekateri izzivi v zvezi z vključenostjo odraslih v izobraževanje. Prvi izziv je povezan $z$ vključenostjo nizko izobraženih (prebivalstva z največ končano osnovno šolo) v izobraževanje, kar je razvojni izziv. Z vidika staranja prebivalstva drugi izziv predstavlja spodbujanje vključenosti starejših (zaposlenih in upokojencev) $\mathrm{v}$ izobraževanje. Veljalo bi spodbuditi večjo vključenost obeh skupin prebivalstva v izobraževanje.

Poleg vključenosti v izobraževanje je $\mathrm{z}$ vidika gospodarskega razvoja pomembna kakovost tega izobraževanja; boljša ko je, večji je pozitivni vpliv izobraževanja na gospodarski razvoj (Hanusek in Woessmann, 2007). Zaradi pomena, ki ga ima kakovost, je treba na ravni politike posebno skrb nameniti spodbujanju kakovosti (z raznimi ukrepi, tudi s finančnim vlaganjem) ter s samoevalvacijami in evalvacijami kakovosti na ravni izobraževalnih ustanov. Za slednje ustanove so tako pridobljene informacije o kakovosti koristna povratna informacija in spodbuda za nadaljnje sprejemanje izboljšav.

$\mathrm{K}$ uveljavljanju vseživljenjskosti učenja in $\mathrm{k}$ večjemu vključevanju nekaterih skupin prebivalstva, ki se zdaj v izobraževanje vključujejo v manjši meri, bo prispevalo tudi izvajanje v letu 2007 sprejete strategije vseživljenjskosti učenja. Za izvajanje strategije pa bi veljalo čim prej sprejeti tudi operativni program ter začeti izvajati ustrezne ukrepe.

\section{LITERATURA IN VIRI:}

Education at a Glance 2008. (2008). Paris: OECD. Eurostat Portal Page - Population and social condition. (2008). Luxembourg: Eurostat. Pridobljeno februarja 2008 na http://epp.eurostat.ec.europa.eu.

Hanusek E. A. in Woessmann L. (2007). The role of school improvement in economic development. Cesifo working paper No. 1911. Category 5: Fiscal policy, macroeconomics and growth. Dostopno tudi na: http://www.cesifo.de/CESifoPortal.

Hanusek, E. A. in Woessmann, L. (2007). Education quality and economic growth. Washington: The World Bank.

Lizbonska strategija. Dostopno na: http://ec.europa. eu/growthandjobs/index_en.htm

Memurandum o vseživljenjskem učenju. (2000). Bruselj: Komisija Evropske skupnosti.

Population and social condition - Eurostat Queen tree, 2008. Dostopno na: http://epp.eurostat.ec.europa.eu/ portal/page?_pageid=1090,30070682,1090_3307657 6\&_dad=portal\&_schema=PORTAL

Report of the Eurostat Task force on measuring lifelong learning. (2001). Bruselj: European Commission.

Resolucija o nacionalnem programu odraslih v Sloveniji do leta 2010. Ur.1. RS št. 70/2004).

Si-STAT podatkovni portal - Demografsko in socialno področje - Izobraževanje. (2008). Pridobljeno februarja 2008 na http://www.stat.si.

Strategija vseživljenjskosti učenja v Sloveniji. (2007). Jelenc (ur.). Ljubljana: Ministrstvo za šolstvo in šport, Pedagoški inštitut.

Temple J. (2001). Growth effects of education and social capital in the OECD countries. Pariz: OECD. Dostopno tudi na: http://www.oecd.org/ dataoecd/26/45/18452154.pdf.

Woessmann L. in Schultz, G. (2006). Efficiency and equity in European education and training systems. Analytical report for the European Commission. Evropska komisija, European expert network on economics of education (EENEE). Dostopno tudi na: http:// ec.europa.eu/education/policies/2010/doc/eene.pdf.

Vossensteyn, H. (2007). Challenges in student financing: State financial support to students - a worldwide perspective. Prispevek na konferenci «Funding, equity and efficiency«, 21.-24. 11. 2007, Portorož.

Santiago, P., Tremblay, K., Basri, E., Arnal, E. (2008). Tertiary education for the knowledge society. Paris: OECD.

${ }^{1}$ Zgodnejša, ko je uporaba znanja po tem, ko je bilo znanje pridobljeno, večji je vpliv na gospodarsko rast. 
${ }^{2}$ Indikator meri vključenost prebivalstva, starega od 25 do 64 let $v$ izobraževanje in usposabljanje v obdobju štirih tednov pred izvajanjem ankete o delovni sili. Indikator je izračunan na osnovi letnega povprečja in se ne nanaša le na eno četrtletje v letu.

3 Vir. Eurostat, lastni preračuni.

4 Terciarno izobraževanje $v$ Sloveniji obsega redno in izredno vpisane na višješolski strokovni študij, visokošolski strokovni in dodiplomski in univerzitetni študij in na visokošolski podiplomski študij (specialistični in magistrski ter doktorski študij). 